This is an electronic reprint of the original article. This reprint may differ from the original in pagination and typographic detail.

Author(s): Kokko, Sami

Title: $\quad$ Guidelines for Youth Sports Clubs to Develop, Implement, and Assess Health Promotion Within Its Activities

Year: $\quad 2014$

Version:

Please cite the original version:

Kokko, S. (2014). Guidelines for Youth Sports Clubs to Develop, Implement, and Assess Health Promotion Within Its Activities. Health Promotion Practice, 15(3), 373382. https://doi.org/10.1177/1524839913513900

All material supplied via JYX is protected by copyright and other intellectual property rights, and duplication or sale of all or part of any of the repository collections is not permitted, except that material may be duplicated by you for your research use or educational purposes in electronic or print form. You must obtain permission for any other use. Electronic or print copies may not be offered, whether for sale or otherwise to anyone who is not an authorised user. 
Health Promotion Practice

\section{Guidelines for youth sports clubs to develop, implement and assess health promotion within its activities}

\section{Introduction}

The settings approach to health promotion has evolved over twenty years and has become one of the focal approaches in the field (Golden \& Earp, 2012; Richard, Gauvin \& Raine, 2011). The evolution of the approach redirected the main focus in health promotion from individual-based risk orientation, towards environment- and context-related factors with orientation on recourses i.e. salutogenic perspective (Kickbush 2003). The fundamentals of the settings approach are its ecological roots (Green et al., 2000) and emphasis on a whole system approach i.e. systems thinking (Dooris, 2004) (Table 1). The approach has primarily been focussed on settings like cities, schools, workplaces and hospitals, but recently a need to broaden the approach towards other, non-traditional, non-institutional settings has been proposed (Dooris, 2013). The youth sports club is one of the new, under-utilized, but developing settings for health promotion (Kokko, Green \& Kannas, 2013). The concept of the health promoting sports club (HPSC) was launched in 2004 in Finland (Kokko, 2005), and it has thereafter been expanded across Europe (Geidne, Quennerstedt \& Eriksson, 2013; Van Hoye, Sarrazin, Kokko \& Heuze, 2013), as well as internationally (Donaldson \& Finch, 2012), especially in Australia (Casey, Payne \& Eime, 2012; Dobbinson, Hayman \& Livingston, 2006; Kelly et al., 2013).

Table 1 Shared and settings-specific features of health promoting settings described in the health promotion literature, with a sports club addition (Kokko 2010). 


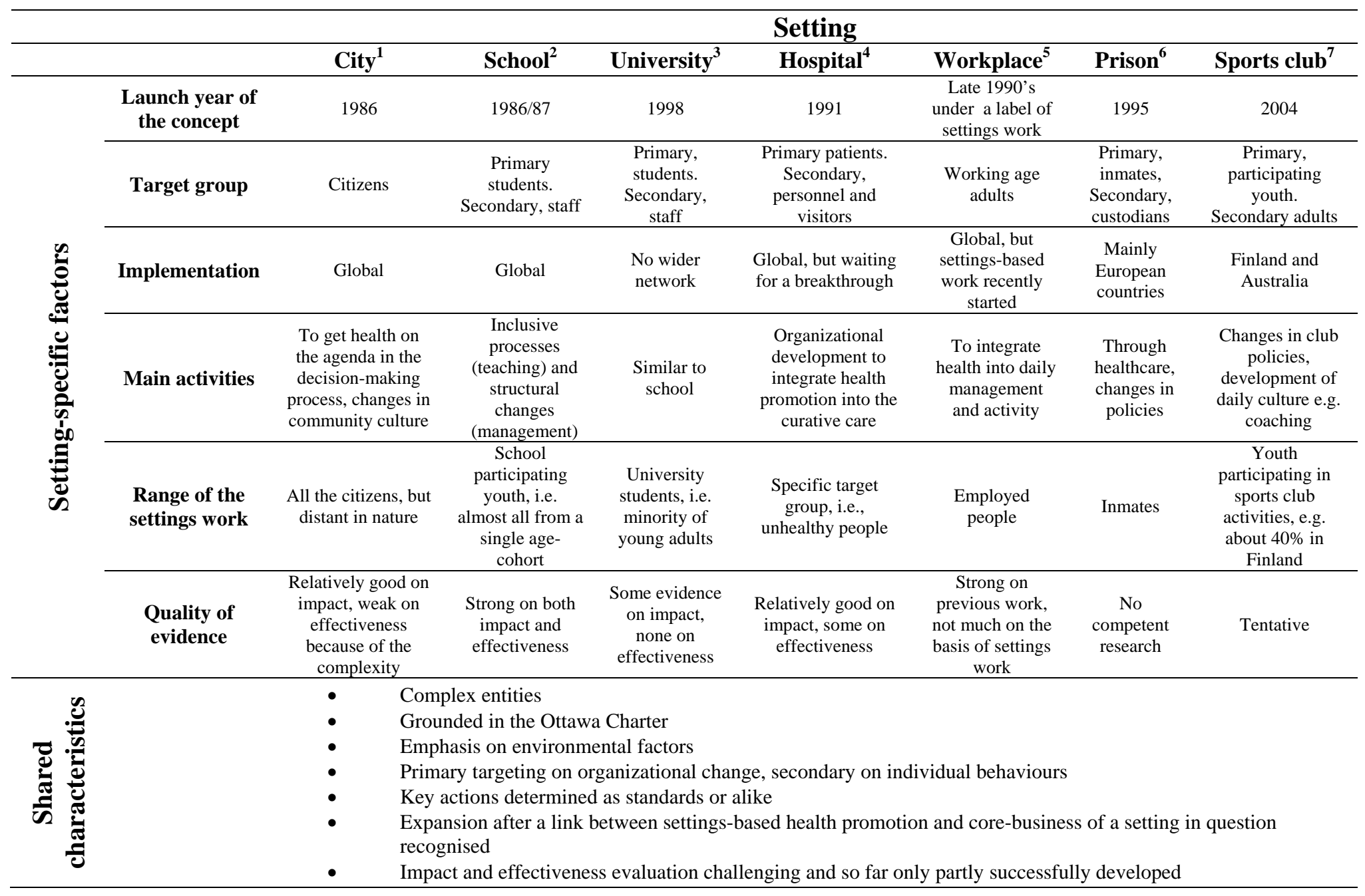

Together with having a focus on development of the academic concept, many of the research projects have a close relationship to practical implications and applications. Therefore, the aim of this article is, on the basis of the Health Promoting Sports Club survey in Finland, to present the guidelines for youth sports clubs to enhance health promotion as a part of their daily activities.

\footnotetext{
1 e.g. Awofeso, 2003; Baum et al., 2006; de Leeuw, 2001; Hancock, 1993

2 e.g. Lee et al., 2008; Lynagh et al., 1997; Michaud, 2003

3 e.g. Dooris, 2001; Tsouros et al., 1998; Xiangyang et al., 2003

4 e.g. Groene et al., 2005; Johnson, 2000; Pelikan et al., 2001; Whitehead, 2004

${ }^{5}$ e.g. Chu et al., 2000; Engbers et al., 2005; WHO, 2003b

${ }^{6}$ e.g. Department of Health, 2002; Squires, 1996; WHO, 2003a

7 e.g. Dobbinson et al., 2006; Author, 2010; Author et al., 2009
} 


\section{Background}

Sports clubs are prevalent leisure-time settings for children and adolescents in many countries. Overall, club activities attain between a third and $70 \%$ of children and adolescents in different European countries (Heinemann, 1999). In Finland, clubs reach almost half of the youth (Vuori et al., 2007). Owing to the significant societal position and wide accessibility, demand for youth sports club activities is widespread. Despite the fact that the main function of youth sports clubs is organizing physical activity with the emphasis on competitive sports, many expectations beyond sports exist. Many authorities, for example, have also acknowledged that the sports sector at all levels should recognise its responsibility for the enhancement of public health. At the same time, sports federations and clubs themselves have determined that the objectives of club activities are broader than just organizing or concentrating on sports. Indeed, $81 \%$ of Finnish youth sports clubs declare that healthy lifestyle is one of the main goals of their activities (Koski, 2009).

These health-related goals have not, so far, reached the ultimate target group, as two Finnish nationwide surveys indicated at the beginning of the millennium. According to the surveys, youth who participate in sports club activities are more physically active and smoke less than their nonparticipating peers, but negative aspects, such as heavy drinking and more frequent oral snuff use were also found (Kannas et al., 2002; Rimpelä, 2000). The studies undermined the myth of sports clubs' automatic positive contribution to children’s and adolescents’ health behaviours.

Youth sports club activities have a lot of potential in the area of health promotion. A club is more than a place for physical activity; a youth sports club is a setting in which children and adolescents are influenced by the people within that setting and receive advice on many health issues. Still, health and especially health promotion has been studied less in this context, and when studied, the main focus has 
been on injury prevention or different kinds of interventions in which sports have been used externally as a vehicle to execute prevention on some specific health topic such as alcohol use (Werch et al., 2003) or eating disorders (Abood \& Black, 2000; Elliot et al., 2004). The idea of the health promoting sports club concept, and therefore the associated guidelines, is a) to get clubs to recognize that investment in health promotion is beneficial to their core-business i.e. athlete development/sports performance, b) to integrate the health promotion actions into the existing "sports" operations and c) guide the clubs in this process in order to get more local level health promotion actions. Despite of variation in sports systems in different countries, the youth sports club mission is generally the same to organise sports activities. Therefore, these guidelines form a basis for local applications for the majority of the countries.

\section{Process of developing guidelines}

The Health Promoting Sports Club survey in Finland consisted of 97 youth sports clubs from four sport disciplines (ice-hockey, soccer, cross-country skiing and athletics) and was conducted in 2007. The clubs' health promotion orientation was examined first and both clubs' and coaches health promotion activity next (Kokko et al., 2006, 2009; Kokko et al., 2011a; Kokko, 2010). The guidelines were developed in the light of these results and implications derived from those, but were strengthened by other evidence in the field of settings-based health promotion (Figure 1) (Kokko, 2010). Finally, in formulating the guidelines, general principles of health promotion planning and evaluation were used as reflective and guiding material, for example in order to follow the correct sequence and to acknowledge all the relevant factors of a development process (e.g. Donovan \& Henley, 2003; Green \& Kreuter, 2005; Laverack, 2007; Tones \& Green, 2004). 


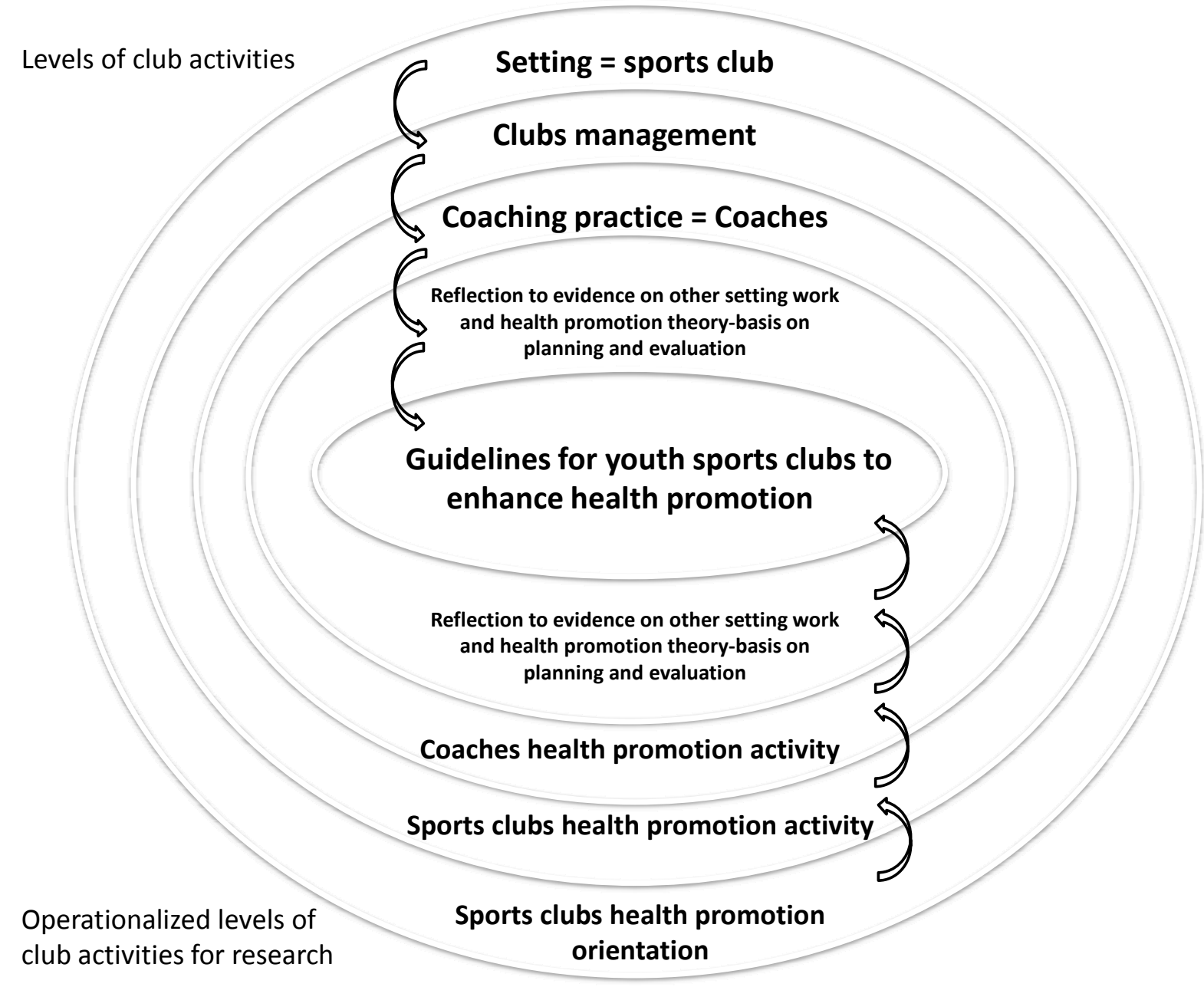

Figure 1 The process of guideline development: from research to guidelines with reflections to existing evidence on other settings work and theory-basis of health promotion planning and evaluation.

The guidelines are divided under policy and practice levels. These levels both refer to club-level activities: policy referring to those, mainly written, principles that are aimed to guide the daily activities, and practice levels referring to those activities a club needs to perform before its daily actors (mainly coaches) can be active. The latter refers specifically to the fact that a club needs to create the best possible pre-conditions for its actors to act on. Guidelines are arranged in a sequence, therefore forming a step-by-step model a club can follow. A single guideline is presented in a three-level structure. First, the actual guideline is presented; second, the importance of a guideline is reasoned and justification for the guideline in question stated; and finally, a practical example is illustrated. 


\section{Guidelines for policy development}

Policy in sports clubs refers to publicly established determinants or guidelines of the objectives and philosophy and activities of the club, or as VicSport (2008) has determined “A policy is a guide to action and decision-making under a given set of circumstances that assures consistency and fairness within the framework of your (sports clubs ${ }^{8}$ ) objectives and philosophy.”

\section{Guideline 1: Determine the current state of will to practice health promotion in your club.}

Reasoning: If there is enough endorsement and positive attitude towards health promotion, it is more likely that people are ready for change and will engage to the related aims (Green \& Kreuter, 2005; Tones \& Green, 2004). Similarly to the situation around Health in All Policies ideology in Europe (Ritsatakis and Järvisalo, 2006), there might be a need to initially raise awareness of the need for health promotion before moving forward.

Practical example: A club could arrange a workshop in which participants from various stakeholder groups (club officials, coaches, athletes and parents) have an opportunity to express their opinions about fundamental aims of the club activities and/or of the importance of health promotion as one of the aims. A consensus statement is the goal, or if this seems to be too ambitious, a club can debate on their health promotion position during an executive committee meeting.

\section{Guideline 2: Determine the health promotion aims, turn these into a written form, and convert the aims into the "language of sports".}

Reasoning: If the above mentioned consensus is reached and health promotion determined as one of the fundamental aims, more detailed aims should be generated. These aims should thereafter be

\footnotetext{
${ }^{8}$ Author's remark.
} 
transformed into a written form (Dobbinson et al., 2006). When the health promotion aims are in a written form, it is then transparent and publicly stated, and the written text remains even though people may change. It is also important to use sports-related terminology in order to address people in a sports club context i.e. tailored message to target group (Grier \& Bryant, 2005).

Practical example: Often, the prior aims of Finnish sports clubs are written into the association regulations. Sometimes the clubs also have written operational principles. Health promotion should be included in, or added to both of these. An example of sports-related terminology here is instead of using a concept of healthy lifestyle, use a concept of sporty lifestyle. It can thereafter also be determined more specifically what is meant by sporty lifestyle, such as if it includes nutrition, substance-free habits etc.

\section{Guideline 3: Prioritize the most relevant health promotion aims.}

Reasoning: There are several health-topics in health promotion that can be targeted, such as, physical activity, nutrition, sleep, substance-use prevention and mental health. Also, policy and practice level activities differ from each other. Therefore, it is important to consider which health promotion aims are relevant, suitable and feasible for each club, relative to other sports-related aims and resources. The current evidence indicates that overall physical activity levels of young athletes are too low (Eiosdottir et al., 2008) and substance-related issues are surprisingly rarely discussed by the coaches (Kokko 2010).

Practical example: One possible starting point could be to choose three or four health-topics that are deemed to be the most important. A three or four year plan can then be formulated, during which one topic will be concentrated on each season. For example: in the first year, substance-use prevention; second year, nutrition; third year, sleep-issues; and so on. Thereafter, prior activities should be selected. This varies depending on the club in question. A club that has not done much yet needs first to create 
substance-related policies, for example, making a stand on alcohol use of adults involved with club activities; is it allowed or not, and if it is, where and how much? A club that has already made these definitions of policy may develop its policy further. It may, for example, consider how smoking by an athlete should be intervened in; does a coach in this kind of situation always need to inform the parents or not? If not, when not, such as after the first time? And how should a coach react to and approach this situation, e.g. advice the athlete on the disadvantages and health issues related to smoking?

\section{Guideline 4: Consider both financial and human resources that can be invested in the health promotion development work.}

Reasoning: It is important to realize that any development process needs resources, at least human and time resources (Green \& Kreuter, 2005). There might also be financial possibilities available; consider for example your clubs capabilities to apply for money (cf. Kokko et al., 2011b).

Practical example: Create a realistic timeline for the development. Consider who needs to do what; what is a reasonable input i.e. time resource that a head of coaching or coaches invest in this, annually and for the three year period? Examine possible and available financial sources, and the requirements for applications. You can also try to discover if someone could be available to consult your club possibly a parent of an athlete?

\section{Guideline 5: Designate a certain person to lead the development process.}

Reasoning: Previous research found that there were notably more health promotion policies in a club in which the policy development was assigned to a certain person (Dobbinson et al., 2006). In most of the cases, there were no designated persons to develop health-related policies, and therefore, by this nomination of a coordinator, the development gains recognition and support. 
Practical example: This designated person can be a member of executive committee or another club official. The person can also be a parent of an athlete; there might be someone among the parent body who has a profession related to healthcare or a common interest in health promotion. Development can also be directed to a working group, but it is important that it is official and has a leader.

\section{Guideline 6: Engage all the participating club officials.}

Reasoning: It is important to realize that there will be resistance to change (Tones \& Green, 2004). It is important to get all the club officials to act towards the same goals, and active and tailored communication is needed (Donovan \& Henley, 2003). Early adaptors and/or opinion leaders may be used as facilitators to engage others (Dearing et al., 2006).

Practical example: internal organizational communication is crucial in this aspect. A club should inform all stakeholders about the health-related aims and policies. Existing channels of communication and forums such as parents' meetings may be used. It is important to continue this communication throughout the season, in which case, good practice by early adaptors, such as successful nutrition education, should be used as examples and to boost the motivation of others.

\section{Guideline 7: Collaborate with other clubs.}

Reasoning: Sharing ideas on policies and best practice is a way to improve health promotion without always needing to create everything by oneself (cf. various documents on best practices in sports). Training and/or advice were notable enabling factors for policy development (Dobbinson et al., 2006) and other clubs and sports organizations may also offer attitudinal support in acting towards a mutual goal (Dearing et al., 2006). 
Practical example: Collaboration can be used in many practical actions such as in organizing coaching education. Collaboration can be with other clubs from the same discipline, but also with clubs from other disciplines. Existing contacts are the way to start.

\section{Guideline 8: Evaluate the feasibility of health promotion aims regularly.}

Reasoning: It is important to notice that the planning of evaluation should be started right at the beginning of the development process (Green \& Kreuter, 2005). However, evaluation methods should be adequate and suitable for this kind of use (Table 2). It should be remembered that the purpose of evaluation is first of all the development of activities, through finding out whether the existing activities are effective with relation to the policies. Proper evaluation plans, methods and indicators for both the short and long term should be created.

Practical example: The main point in evaluation is the same for sports and health related aims; are policies executed effectively in practice, and are the aims reached? It is a question of having a clear chain between aims, policies, activities and final outcomes. How can we prove that our tobacco policy leads to healthier activities? And that activities lead to an expected outcome? A policy-level example could be the situation in which a club has created a new policy for how the coaches should act in a case of tobacco use by an athlete. It should be monitored whether these occasions have occurred and have the coaches followed the policy (practice evaluation). Thereafter, it can be evaluated whether the policy is feasible and relevant.

\section{Guidelines for practice development}

Practice in youth sports clubs applies to daily activities conducted by different practitioners - mainly coaches - when operating with young athletes. Still, these guidelines are for clubs i.e. sports clubs' role as an organization to increase health promotion within coaching practice. The main question from the 
club's point of view is how to get coaches to execute health promotion actions that have been determined in the club's policies? The answer to this question relies on following key priorities: 1 , coaches should be guided and their motivation and commitment secured; 2, coaches' knowledge and skills need to be improved. This means for example, that a club should arrange education for coaches. Overall, the following guidelines are intended for use on a club-level i.e. which issues club-level actors need to pursue in order to create such pre-conditions that coaches can take over and successfully implement health promotion as a part of their coaching practice.

\section{Guideline 9: Create an action plan for implementing policy-determined aims.}

Reasoning: To ensure that those health promotion aims specified in the club policies are met, one needs to carefully plan what is implemented (content), how (means), when (timing), and by whom (implementing person) (Glanz et al., 2008). A single aim may consist of several activities, which all need to be operationalized so that the previous particulars (content, means, timing and implementing person) are clear.

Practical example: Here again prioritizing is helpful. A club can, for example, choose one health-topic per season to focus on, or alternatively a few activities. The Finnish Ice Hockey Association (FIHA) for example has implemented a three year time cycle for its health promotion program (Kokko, 2007). In this program, the first year focused on substance use prevention, especially snuff use (similar to oral tobacco), second year on nutrition, and third year on sleep/rest and hygiene, under which several possible activities were established.

\section{Guideline 10: Invest in internal organizational communication i.e. guidance activity.}

Reasoning: To get club-level policies into practice, a club needs to invest heavily in communication. The main idea here can be simplified into a saying, "even the best policy will not lead to good practice, 
if it has not been successfully communicated to practice-level actors” (Whisenant \& Pedersen, 2004a, b). This refers mainly to the activity of club officials towards coaches.

Practical example: This guidance can be in an oral, written or educational form. It is again important to recognize that the selection of proper means is dependent upon the existing ones. This means for example, that if a club has a tradition of having a conversation between club officials and coaches at the beginning of season, then this existing forum should be used. On the other hand, health promotion emphasis can be integrated into a coach's contract, if there is a tendency to do one. Also, if a club has an internal education system for coaches and other officials, health promotion matters can be integrated into those.

\section{Guideline 11: Motivate the coaches regarding the importance of health promotion.}

Reasoning: A key to success in traditional settings-based initiatives has been the raising of awareness of the link between the core-business of the setting and health promotion (Kokko, 2010). This is also central to motivating the coaches to become more interested in health-related matters. Once again, it is important to use the language of sports and crucial to turn the focus of justification from health being important as recognized in youth sports because of societal importance, to health being important because of sports and sporting youth.

Practical example: This motivation enhancement can only be done by getting the coaches to consider the issue as part of a normal coaching education. Coaches must consider this issue themselves, and through their own coaching behaviour and athletes' behaviour, consider what is the meaning of health in sports and to athletes? You might also turn this approach on its head and contemplate what happens if your athlete is unhealthy while training? What if your athletes only eat unhealthy food, like junk food? What would you think if your athletes smoke immediately after some hard training? And, after 
these considerations, personalize the health issue by asking how much a coach has invested into these issues, and/or should/will invest in future?

\section{Guideline 12: Educate coaches and other club officials.}

Reasoning: According to research findings, sports coaches are willing to enhance the volume of health promotion and education within their coaching practice, but they lack the relevant knowledge and skills (Kokko \& Kannas, 2004). It is therefore likely that a similar situation exists among other club officials. For a club to expect coaches and other club officials to increase health promotion activities, education must be provided beforehand.

Practical example: There are basically two ways of providing education for coaches and officials; internally and/or externally. Internal education can be done in two ways: Health promotion matters might be integrated into existing educational activities such as coaching education, or health promotion specific training might be arranged. External education is provided by many parties, such as national sports federations, regional sports organizations, or a health organization (first aid). Consider how you could encourage people to participate, for example by possibly paying their participation fees and other costs if possible.

\section{Guideline 13: Monitor health promotion activities in daily practice.}

Reasoning: There are usually many different sub-groups (e.g. teams) within a sports club. It is important to ensure that all of these sub-groups are following the health promotion policy or operating principles of the club. This means that a club and its officials should regularly observe the daily activities of teams to assess the prevalence of health promotion activities (Table 2).

Practical example: This observation can be done in many ways, such as discussions with coaches, parents or athletes, or through questionnaires. Active monitoring during the whole season will help the 
evaluation process, as information is gathered throughout the season and not only one point in time (end of season). Monitoring also provides knowledge during a season, allowing for possible modification if a policy or practice is not working properly, and it is recognized that it is possible to rectify it.

\section{Guideline 14: Evaluate practices with relation to policies.}

Reasoning: As it was important in the policy level to evaluate the feasibility of health-related policies, it is here important to evaluate whether the activities executed meet the aims of the policy (Table 2). Overall, the evaluation is important for two reasons: First, it is important because it helps to improve the development process, and second, it is possible to gather evidence to demonstrate the benefits derived from the activities.

Practical example: The key point in evaluation is to recognize links between the aims, activities and expected outcomes. For example, if the aim is to increase knowledge of the coaches, the activities done in order to improve this knowledge should be monitored, and thereafter the improvement in coaches' knowledge should be objectively measured. Another example relating to the policy level is a new policy for tobacco use intervention when monitoring should focus on how many occasions smoking has been observed, and have the coaches followed the policy procedures. Furthermore, the effect of the intervention on the youth should be evaluated. It should be highlighted here that the evaluation methods depend on the resources and knowhow available, and the most important consideration is that evaluation is completed in some form and is acknowledged throughout the process.

Table 2 Characteristics and examples of 1) Process evaluation 2) Monitoring and 3) Impact/outcome evaluation of health promotion in a sports club setting (applied from Green \& Kreuter, 2005; Glasgow \& Linnan, 2008). 


\begin{tabular}{|c|c|c|c|c|c|}
\hline $\begin{array}{l}\text { Types of } \\
\text { evaluation }\end{array}$ & When? & Why? & What? & $\begin{array}{l}\text { By whom? / } \\
\text { From whose? }\end{array}$ & $\begin{array}{l}\text { Example on a new policy on } \\
\text { substance-free environment. }\end{array}$ \\
\hline $\begin{array}{l}\text { Process } \\
\text { (Feasibility) } \\
\text { evaluation }\end{array}$ & $\begin{array}{l}\text { Starting right from } \\
\text { beginning of the } \\
\text { planning process } \\
\text { (guidelines } 2 \& 8 \text { ). }\end{array}$ & $\begin{array}{l}\text { In order to evaluate } \\
\text { whether the policies } \\
\text { are executed as } \\
\text { planned. }\end{array}$ & $\begin{array}{l}\text { Documenting all } \\
\text { the activities and } \\
\text { processes executed. }\end{array}$ & $\begin{array}{l}\text { By club officials } \\
\text { from coaches and } \\
\text { other daily actors, } \\
\text { such as team } \\
\text { managers. }\end{array}$ & $\begin{array}{l}\text { Document the activities done to } \\
\text { reinforce policy implementation } \\
\text { and ask whether the activities } \\
\text { aimed for coaches and others to } \\
\text { implement are feasible on their } \\
\text { opinion. }\end{array}$ \\
\hline Monitoring & $\begin{array}{l}\text { During the } \\
\text { implementation } \\
\text { process (one sports } \\
\text { season, guideline } \\
\text { 13). }\end{array}$ & $\begin{array}{l}\text { To collect } \\
\text { information for } \\
\text { evaluation over the } \\
\text { implementation } \\
\text { period. }\end{array}$ & $\begin{array}{l}\text { Gathering } \\
\text { information of HP } \\
\text { policies from the } \\
\text { daily actors by } \\
\text { discussions, } \\
\text { questionnaires etc. }\end{array}$ & $\begin{array}{l}\text { By club officials } \\
\text { from coaches and } \\
\text { other daily actors, } \\
\text { such as team } \\
\text { managers. }\end{array}$ & $\begin{array}{l}\text { Ask about the realization of the } \\
\text { policy in daily activities and } \\
\text { within various sub-groups in a } \\
\text { club. There might be variation on } \\
\text { the realization. }\end{array}$ \\
\hline $\begin{array}{l}\text { Impact/ } \\
\text { outcome } \\
\text { evaluation }\end{array}$ & $\begin{array}{l}\text { At the end of the } \\
\text { process (annually, } \\
\text { at the end of the } \\
\text { season, guideline } \\
\text { 14). }\end{array}$ & $\begin{array}{l}\text { To evaluate } \\
\text { whether the actions } \\
\text { done meet the aims } \\
\text { of the policies. }\end{array}$ & $\begin{array}{l}\text { Evaluate what are } \\
\text { the immediate } \\
\text { impacts of the } \\
\text { actions realized and } \\
\text { possible later on } \\
\text { long-term } \\
\text { (outcome). }\end{array}$ & $\begin{array}{l}\text { By club officials } \\
\text { from various } \\
\text { respondent groups } \\
\text { including, coaches } \\
\text { and other daily } \\
\text { actors, athletes and } \\
\text { parents. }\end{array}$ & $\begin{array}{l}\text { Ask from various respondents } \\
\text { have they observed improvements } \\
\text { in the environment in terms of } \\
\text { substance-free facility i.e. less } \\
\text { smoking or drinking? }\end{array}$ \\
\hline
\end{tabular}

\section{Concluding remarks}

The basis of the guidelines is to firstly recognize that the development of health promotion in the youth sports club setting is a process, not a project, which will and should take time. Health promotion is not always identified as the core-business of sports, which may cause resistance, which may be overcome when a link between health promotion and sports performance is justified. Secondly, the guidelines emphasize that health promotion can and should be integrated into existing sports-related policies and practices. Often it is "only" a question of a slight change of point of view or opinion. Again, it is a question of realizing the close relationship between health promotion and existing sports activities. Finally, it should be recognized that improved health promotion activity not only benefits public health goals, but will most likely have positive effects on the health behaviors, health and overall wellbeing of sporting children and adolescents, and through these, have a beneficial effect on sports performance itself. Added investment in health promotion could also be one response to health problems of contemporary society such as obesity. Youth sports clubs are facing the same problems and health 
issues as society in general i.e. more children commencing activities are obese. This cannot be ignored, but should be regarded as a challenge from the perspective of athlete development.

\section{References}

Abood, D.A. \& Black, D.R. (2000) Health education prevention for eating disorders among ollege female athletes. American Journal of Health Behavior, 24, 209-219.

Awofeso, N. (2003) The healthy cities approach - reflections on a framework for improving global health. Bulletin of the World Health Organization, 81, 222-223.

Baum, F., Jolley, G., Hicks, R., Saint, K. and Parker, S. (2006) What makes for sustainable healthy cities initiatives? - a review of the evidence from Noarkunga, Australia after 18 years. Health Promotion International, 21, 259-265.

Casey, M., Payne, W.R. \& Eime, R.M. (2012) Organisational readiness and capacity building strategies of sporting organisations to promote health. Sport Management Review, 15, 109-124

Chu, C., Breucker, G., Harris, N., Stitzel, A., Gan, X., Gu, X. and Dwyer, S. (2000) Health-promoting workplaces - international settings development. Health Promotion International, 15, 155-167.

Dearing, J.W., Maibach, E.W. \& Buller, D.B. (2006) A Convergent Diffusion and Social Marketing Approach for Disseminating Proven Approaches to Physical Activity Promotion. American Journal of Preventive Medicine, 31, 11-23.

de Leeuw, E. (2001) Global and local (glocal) health: the WHO healthy cities programme. Global Change \& Human Health, 2, 34-45.

Department of Health (2002) Health promoting prisons: A shared approach. London: Department of Health.

Dobbinson, S.J., Hayman, J.A. \& Livingston, P.M. (2006) Prevalence of health promotion policies in sports clubs in Victoria, Australia. Health Promotion International, 21, 121-129. 
Donaldson, A. \& Finch, C.F. (2012) Sport as a setting for promoting health. Br J Sports Med 46, 4-5.

Donovan, R. \& Henley, N. (2003) Social marketing. Principles and practice. Melbourne: IP Communications.

Dooris, M. (2001) The "Health promoting university": A critical exploration of theory and practice. Health Education, 101, 51-60.

Dooris, M. (2004) Joining up settings for health: a valuable investment for strategic partnerships? Critical Public Health, 14, 37-49.

Dooris, M. (2013) Expert voices for change: Bridging the silos - towards healthy and sustainable settings for the $21^{\text {st }}$ century. Health \& Place, 20, 39-50.

Eiosdottir, S.P., Kristjansson, A.L., Sigfusdottir, I.D. and Allegrante, J.P. (2008) Trends in physical activity and participation in sports clubs among Icelandic adolescents. European Journal of Public Health, 18, 289-293.

Elliot, D.L., Goldberg, L., Moe, E.L., DeFrancesco, C.A., Durham, M.B. \& Hix-Small, H. (2004) Preventing substance use and disordered eating: Initial outcomes of the ATHENA (athletes targeting healthy exercise and nutrition alternatives) program. Archives of Pediatrics \& Adolescent Medicine, 158, 1043-1049.

Engbers, L.H., van Poppel, M.N.M., Chin A Paw, M.J.M. and van Mechelen, W. (2005) Worksite health promotion programs with environmental changes. A systematic review. American Journal of Preventive Medicine, 29, 61-70.

Geidne, S., Quennerstedt, M. \& Eriksson, C. (2013) The youth sports club as a health-promoting setting: An integrative review of research. Published online 24 January 2013 Scand J Public Health DOI: $10.1177 / 1403494812473204$

Glanz, K., Rimer, B.K. \& Viswanath, K. (2008) (eds.) Health Behavior and Health Education: Theory, Research, and Practice. $4^{\text {th }}$ Edition. San Francisco: Jossey-Bass. 
Golden, S.D. \& Earp J.A. (2012) Social ecological approaches to individuals and their contexts: twenty years of Health Education \& Behavior health promotion interventions. Health Education \& Behavior, 39, 364-372.

Green, L.W., Poland, B.D. and Rootman, I. (2000) The settings approach to health promotion. In Poland, B., Green, L. and Rootman, I. (eds.) Settings for health promotion. Linking theory and practice. California: Sage Publications Inc., pp. 1-43.

Green, L.W. \& Kreuter, M. (2005) Health program planning: An educational and ecological approach. $4^{\text {th }}$ edition. New York: McGraw-Hill. co.

Grier, S. \& Bryant, C.A. (2005) Social Marketing in Public Health. Annual Review of Public Health, 26, 319-339.

Groene, O. (2005) Evaluating the progress of the health promoting hospitals initiative? A WHO perspective. Health Promotion International, 20, 205-207.

Heinemann, K. (1999) Sports clubs in Europe. In Heinemann, K. (ed.) Sport clubs in various European countries. Series Club of Cologne, Vol 1. Stuttgart: Hofmann Verlag and Schattauer, pp. 13-32.

Hancock, T. (1993) The Evolution, impact and significance of the healthy cities/healthy communities movement. Journal of Public Health Policy, 14, 5-18.

Johnson, J. L. (2000) The health care institutions as a setting for health promotion. In Poland, B., Green, L. and Rootman, I. (eds.) Settings for health promotion. Linking theory and practice. California: Sage Publications Inc., 175-216.

Kannas, L., Vuori, M., Seppälä, H.-R., Tynjälä, J., Villberg, J., Välimaa, R. \& Ojala, K. (2002) Suojaako urheiluseuratoiminta nuoria päihteiltä ja tupakalta [Do the sports club’s actitivities protect from intoxicants and tobacco]. Liikunta \& Tiede, 39, 4-11.

Kelly, B., King, L., Bauman, A.E., Baur, L.A., Macniven, R., Chapman, K. \& Smith, B.J. (2013) Identifying important and feasible policies and actions for health at community sports clubs: A 
consensus-generating approach. J $\quad$ Sci $\quad$ Med http://dx.doi.org/10.1016/j.jsams.2013.02.011

Kickbusch, I. (2003) The contribution of the World Health Organisation to a new public health and health promotion. American Journal of Public Health 93, 383-388.

Kokko, S. (2005) Sports clubs as a setting for youth health promotion. In Hoikkala, T., Hakkarainen, P. and Laine, S. (eds.) Beyond health literacy. Youth cultures, prevention and policy. Finnish youth research network / Finnish youth research society publications 52, 338-354.

Kokko, S. (2007) Operaatio urheilullinen elämäntapa - Suomen Jääkiekkoliiton terveyden edistämisohjelma [Operation sporty lifestyle - The health promotion program of the Finnish Ice Hockey Association]. Accessed 26.8.2009.

Kokko, S. 2010. Health Promoting Sports Club - Youth Sports Clubs' Health Promotion Profiles, Guidance, and Associated Coaching Practice, in Finland. University of Jyväskylä, Studies in Sport, Physical Activity and Health 144, 147 pages.

Kokko, S. \& Kannas, L. (2004) Terveyskasvatus nuorten jääkiekkovalmennuksessa [Health education in ice hockey coaching of adolescents]. Liikunta \& Tiede, 41, 45-48.

Kokko, S., Kannas, L. \& Villberg, J. (2006) The health promoting sports club in Finland - a challenge for the settings-based approach. Health Promotion International, 21, 219-229.

Kokko, S., Kannas, L. \& Villberg, J. (2009) Health promotion profile of youth sports clubs: club officials' and coaches' perceptions. Health Promotion International 2009, advance access published, doi: 10.1093/heapro/dan040. Health Promotion International, 24, 26-35.

Kokko, S., Kannas, L., Villberg, J. \& Ormshaw, M. (2011a) Health promotion guidance activity of youth sports clubs. Health Education, 111, 452-463. 
Kokko, S., Oja, P., Foster, C., Koski, P., Laalo-Häikiö, E. \& Savola, J. (2011b) Sports Club for Health - Guidelines for a health-oriented sports activities in a club setting. . Finnish Sport for All Association publications. SP-paino: Nurmijärvi.

Kokko, S., Green, L.W. and Kannas, L. (2013) A review of settings-based health promotion with applications to sports clubs. Health Promotion International dat046 first published online June 30, 2013 doi:10.1093/heapro/dat046 (16 pages).

Koski, P. (2009) Liikunta- ja urheiluseurat muutoksessa [Sports clubs in change]. SLU-julkaisusarja 7. Helsinki: SLU-paino.

Laverack, G. (2007) Healt promotion practice. Building empowered communities. Auckland: Open university press.

Lee, A., Wong, M.C.S., Keung, V.M.W., Yuen, H.S.K., Cheng, F. and Mok, J.S.Y. (2008) Can the concept of health promoting schools help to improve students' health knowledge and practices to combat the challenge of communicable diseases: Case study in Hong Kong? BMC Public Health, 8, 42. Online Journal, doi:10.1186/1471-2458-8-42.

Lynagh, M., Schofield, M.J. and Sanson-Fisher, R.W. (1997) School health promotion programs over the past decade: A review of the smoking, alcohol and solar protection literature. Health Promotion International, 12, 43-59.

Michaud, P.-A. (2003) Prevention and health promotion in school and community settings: A commentary on the international perspective. Journal of Adolescent Health, 33, 219-225.

Pelikan, J.M., Krajic, K. and Dietscher, C. (2001) The health promoting hospital (HPH): concept and development. Patient Education and Counseling, 45, 239-243.

Richard, L., Gauvin, L. \& Raine, K. (2011) Ecological Models Revisited: Their Uses and Evolution in Health Promotion Over Two Decades. Annual Review of Public Health, 32, 7.1-7.20. 
Rimpelä, M. (2000) Urheiluseuratoiminnan, kilpaurheilun ja urheiluviestinnän yhteydet lasten päihteiden käyttö [Links between sports club activities, top-sport and sport communications and substance use of children]. Liikunnan ja urheilun maailma (The world of sport and exercise), 4. Accessed 8.9.2009. http://www2.slu.fi/lehtiarkisto/verkkolehti.200004.uutinen.573

Ritsatakis, A. \& Järvisalo, J. (2006) Opportunities and challenges for including health components in the policy-making process. In Ståhl, T., Wismar, M., Ollila, E., Lahtinen, E. \& Leppo, K. (eds.) Health in All Policies. Prospects and potentials. Helsinki: Ministry of Social Affairs and Health, 145-167.

Squires, N.F. (1996) Promoting health in prisons. British Medical Journal, 313, 1161.

Tones, K. \& Green, J. (2004) Health promotion. Planning and strategies. London: SAGE Publications Ltd.

Tsouros, A.D., Dowding, G., Thompson, J. and Dooris, M. (1998) Health promoting universities. Concept, experience and framework for action. Copenhagen: World Health Organization.

Van Hoye, A., Sarrazin, P., Kokko, S. \& Heuze, J.P. (2013) French sport clubs: health promotion activities, missions, and coaches’ motivation. Submitted

VicHealth (2008) A sporting change. The inside knowledge on healthy sports clubs. Victoria: Victorian Health Promotion Foundation.

Vuori, M., Ojala, K., Tynjälä, J., Villberg, J., Välimaa, R. \& Kannas, L. (2007) Saavutetaanko liikuntasuositukset? 11-, 13- ja 15-vuotiaiden liikunta ja tärkeimmät liikuntasyyt WHOKoululaistutkimuksessa vuonna 2006 [Are the physical activity recommendations reached? The physical activity of 11, 13 and 15 year-olds and the most important reasons for physical activity in HBSC Study: Year 2006]. Liikunta \& Tiede, 44, 10-14. 
Werch, C., Moore, M., DiClemente, C., Owen, D.M., Jobli, E. \& Bledsoe, R. (2003) A sport-based intervention for preventing alcohol use and promoting physical activity among adolescents. Journal of School Health, 73, 380-388.

Whisenant, W.A. \& Pedersen, P.M. (2004a), “Traditional managerial activities and interscholastic athletics directors: Examining the differences, similarities, and connections between engagement, gender, and success of high school sports administrators”, Public Organization Review: A Global Journal, 4, 75-84.

Whisenant, W.A. \& Pedersen, P.M. (2004b), "The influence of managerial activities on the success of intercollegiate athletic directors”, American Business Review, 22, 21-26.

Whitehead, D. (2004) The European health promoting hospitals (HPH) project: How far on? Health Promotion International, 19, 259-267.

WHO (World Health Organization) (2003a) Declaration - prison health as part of public health. Copenhagen: WHO European Regional Office.

WHO (World Health Organization) (2003b) Workplace health in the public health perspective. Policy requirements and performance indicators for good practice in health, environment, safety and social management in Enterprises (GP HESME). Copenhagen: WHO European Regional Office.

Xiangyang, T., Lan, Z., Xueping, M., Tao, Z., Yuzhen, S. and Jagusztyn, M. (2003) Beijing health promoting universities: Practice and evaluation. Health Promoting International, 18, 107-113. 